\title{
Makna Upacara Kematian Osongkapali
}

\author{
Amia Lugita ${ }^{1}$, Emizal Amri ${ }^{2}$ \\ ${ }^{1,2}$ Universitas Negeri Padang
}

\section{Email: amialugita7@gmail.com, emizalamri@fis.unp.ac.id}

\begin{abstract}
Abstrak
Penelitian ini menjelaskan makna simbol pada upacara Osongkapali di Nagari Sungai Patai, Sungayang Kabupaten Tanah Datar. Upacara Osongkapali merupakan upacara kematian Penghulu suku, tahapan prosesi yang dilaksanakan sedikit berbeda dengan upacara kematian masyarakat biasa yaitu adanya makna simbol yang digunakan pada upacara Osongkapali. Problem ini dinilai menarik untuk dikaji, mengingat budaya khas masyarakat local ini, sudah banyak yang tidak dipahami maknanya oleh generasi penerus. Pendekatan penelitian ini adalah kualitatif dengan metode etnografi. Pemilihan informan dilakukan secara purposive sampling, dan data dikumpulkan melalui teknik observasi, wawancara, dan studi dokumen. Untuk mendapatkan keabsahan data dipilih teknik triangulasi sumber. Analisis ini didasarkan pada model analisis etnografi yang dikembangkan Cliffort Geertz, meliputi: hermeneutik data, menginterpretasikan data, interpretatif yang dipresentasikan. Hasil penelitian menunjukkan makna simbol pada upacara Osongkapali merupakan penghormatan terakhir kepada "penghulu suku" yang sudah banyak berjasa pada kaumnya, dan suatu bentuk kebesaran penghulu suku.
\end{abstract}

Kata kunci: Makna Simbol, Osongkapali, Sungai Patai, Upacara

Abstract
This research aims to explain the meaning of the symbol in the Osongkapali Ceremony in Nagari Sungai Patai, Sungayang, Tanah Datar Regency. Osongkapali ceremony is a ceremony of death of tribal chiefs, the stage of the procession that is carried out is slightly different from the death ceremony of ordinary people, namely the meaning of the symbols used in the Osongkapali ceremony. This problem is considered interesting to study, given the typical culture of this local community, many have not understood its meaning by the next generation. This research approach is qualitative with ethnographic methods. The selection of informants was done by purposive sampling, and data were collected through observation techniques, interviews, and document studies. To obtain the validity of the data selected source triangulation technique. The analysis is performed with reference to the ethnographic analysis model developed by Cliffort Geertz, including data hermeneutics, interpreting data, interpretive presented. The results show that the meaning of the symbol in the Osongkapali ceremony is the last tribute to the "tribal chief" who has done a lot for his people, and a form of greatness of the tribal chief.

Keywords: Ceremony, Meaning of Symbols, Osongkapali, Sungai Patai

\begin{tabular}{l|l|l} 
Received: October 21, 2021 & Revised: December 16, 2021 & Published: December 20, 2021 \\
\hline
\end{tabular}

Culture \& Society: Journal of Anthropological Research Vol. 3, No. 2, Th. 2021 


\section{Pendahuluan}

Upacara kematian pada masyarakat Nagari Sungai Patai sama halnya dengan upacara kematian masyarakat Islam lainnya di Minangkabau. Akan sedikit berbeda jika yang meninggal adalah Penghulu suku maka akan di laksanakan upacara Osongkapali. Upacara Osongkapali adalah upacara kematian Penghulu suku di Nagari Sungai Patai yang memiliki beberapa tahapan yang wajib untuk dilaksanakan. Istilah Osongkapali adalah keranda untuk membawa jenazah Penghulu suku ke pemakaman. Upacara Osongkapali dilakukan secara bersama dengan anggota keluarga, niniak mamak dan anggota masyarakat. Masyarakat Sungai Patai melaksanakan upacara Osongkapali yaitu suatu bentuk penghormatan terakhir kepada pemimpin kaum sukunya. PelaksanaanUpacara Osongkapali dilaksanakan setelah pelaksanaan upacara kematian sesuai syariat Islam. Masyarakat Sungai Patai menganggap dengan melaksanakan upacara Osongkapali dapat menggambarkan penting dan berjasanya seorang Penghulu suku, juga sebagai bentuk pelestarian kebudayaan dari generasi ke generasi.

Upacara Osongkapali sudah dilakukan secara turun temurun dan masih dilakukan sampai sekarang. Biaya yang dikeluarkan dalam upacara Osongkapali sekitar Rp. 2.000.000, biaya ini dipergunakan untuk menyiapkan peralatan yang digunakan dalam upacara Osongkapali dan juga membayarkan hutang adat Penghulu suku dan digunakan untuk prosesi Marocak. Upacara Osongkapali menjadi upacara yang wajib dilakukan oleh keluarga seorang Penghulu yang telah meninggal. Dengan demikian upacara Osongkapali menjadi hal penting dilakukan di daerah Nagari Sungai Patai, Sungayang Kabupaten Tanah Datar yang sedang berduka cita.

Beberapa penelitian mengungkapkan mengenai upacara kematian (Daniel, 2015, Fauzi, 2014). Penelitian lain juga mengungkapkan yaitu mengenai tahapan Upacara Osongkapali yang dilakukan oleh masyarakat (Fandi, 2015). Sementara itu, belum ada yang membahas tentang makna upacara Osongkapali. Makna upacara kematian bagi masyarakat sebagai pendukung kebudayaan sangat penting karena keunikan kebudayaan dapat mempertahankan dan melestarikan kebudayaan tanpa terjadi kesalahpahaman. Penelitian ini bertujuan mendeskripsikan dan menjelaskan makna simbol dalam upacara Osongkapali di Nagari Sungai Patai, Kecamatan Sungayang, Kabupaten Tanah Datar. Secara akademis, temuan ini dapat dijadikan landasan berpijak bagi penelitian selanjutnya yang tertarik untuk mengkaji upacara Osongkapali.

Dari sudut pandang teori interpretivisme simbolik Cliffort Geertz, pentingnya makna bagi kehidupan manusia adanya suatu pola makna-makna yang ditransmisikan yang terkandung dalam bentuk simbol yang digunakan dalam upacara Osongkapali, dari bentuk simbol-simbol tersebut masyarakat dapat mengembangkan pengetahuannya, mengekspresikan dirinya dan memberikan penilaian makna terhadap upacara Osongkapali (Fandi, 2015). Upacara Osongkapali yang dilaksanakan oleh masyarakat Nagari Sungai Patai dengan menggunakan simbol dalam upacara tersebut masyarakat dapat berpikir bahwa simbol yang digunakan merupakan ciri khas dari upacara Osongkapali, masyarakat dapat memberikan pemahaman terhadap makna simbol dengan begitu masyarakat dapat memberikan suatu tindakan.

Fokus penelitian ini adalah mempelajari makna simbol Upacara Osongkapali. Pada upacara Osongkapali terdapat adanya simbol pada setiap prosesi dan masih dijalankan hingga saat sekarang. Dalam artian ini perlu dijelaskan apa makna simbol yang terdapat pada Upacara Osongkapali ini.

\section{Metode Penelitian}

Penelitian ini merupakan penelitian kualitatif. Dengan pendekatan kualitatif, peneliti berpeluang untuk memperoleh informasi yang detail dan mendalam dari para informan. Dalam penelitian ini data yang didapat maupun lisan, tindakan, simbol, dan foto Dilihat dari segi metodenya, penelitian ini bisa dikategorikan ke dalam studi etnografi. Enografi yang bersifat mendeskripsikan realitas kelompok melalui analisis, pengungkapan pola-pola, pembuatan

Culture \& Society: Journal of Anthropological Research Vol. 3, No. 2, Th. 2021 
tipologi- tipologi dan kategori-kategori yang cendrung bertujuan untuk mendeskripsikan secara detail dan holistik karakteristik perilaku budaya.

Pemilihan informan dilakukan secara purposive sampling: penulis menentukan informan berdasarkan kriteria (tujuan) penelitian (Habsy, 2017). Jumlah informan penelitian ini berjumlah 13 orang, kriteria informan dalam penelitian adalah: elit yang memerintah (Wali Nagari); dan elit yang tidak memerintah (niniak mamak, alim ulama, cadiak pandai, dan bundo kanduang); serta warga masyarakat biasa. Data penelitian ini dikumpulkan melalui: observasi, wawancara mendalam, dan studi dokumen. Pengamatan dilakukan terhadap simbol dari Upacara Osongkapali, Kemudian melakukan wawancara mendalam kepada masyarakat yang terlibat pada Upacara Osongkapali untuk mendapatkan informasi mengenai makna dari simbol. Untuk menjamin keabsahan data, dilakukan teknik triangulasi sumber. Selanjutnya data yang terkumpul, dianalisis dengan mengadopsi model analisis etnografi yang dikembangkan Clifford Geertz (Alkaf, 2013). Model ini dinilai relevan untuk penelitian kualitatif karena berakomodasi sudut pandang dari pemilik budaya itu sendiri.

\section{Hasil dan Pembahasan}

\section{Nagari Sungai Patai}

Pembentukan suatu nagari umumnya di daerah kawasan Minang sejak dahulunya sesuai istilah pepatah, yaitu darat Taratak manjadi Dusun, dari Dusun manjadi Koto, dari Koto manjadi Nagari. Jadi terbentuknya sebuah Nagari di Minangkabau dimulai dari Taratak, kemudian berkembang menjadi Dusun, selanjutnya berkembang menjadi Nagari. Biasanya setiap nagarari yang terbentuk tersebut minimal telah terdiri dari 4 suku yang berdomisili di kawasan tersebut (Dt. Batuah \& A Dt. Madjoindo,1959)

Nagari Sungai Patai merupakan salah satu dari 5 (lima) nagari yang terdapat di Kecamatan Sungayang. Nagari Sungai Ptai memiliki 2 (dua) jorong, yaitu jorong Talago Jaya dan Bungo Satangkai. Adapun luas Nagari Sungai Patai 11 kilometer persegi atau 16,81 persen dari luas wilayah Kecamatan Sungayang. Nagari Sungai Patai berjarak $5 \mathrm{~km}$ dari ibu kota Kecamatan Sungayang dan $13 \mathrm{~km}$ dari ibu kota kabupaten Tanah Datar (Batusangkar). Secara umum nagari Sungai Patai merupakan daerah berhawa sejuk dan tanahnya subur, sedangkan iklim. Secara umum mempunyai iklim kemarau dan penghujan.

Aturan adat yang dipakai di Nagari Sungai Patai tersebut tertuang dalam ungkapan adat yang berbunyi:

"Ramo-ramo sikumbang jati, kati' endah pulang bakudo, patah tumbuah hilang baganti, soko lamo baitu juo. Biriak-biriak tabang ka sasak, dari sasak tabang ka halaman, dari niniak turun ka mamak dari mamak turun ka manakan.."

Artinya:

Rama-rama si kumbang janti, Kaitik Endah pulang berkuda, patah tumbuh hilang berganti, Barik-barik terbang ke sasak, dari sasak terbang ke halaman, dari nenek/ kakek turun ke mamak dari mamak turun ke kemanakan

Maksud kata-kata adat di atas adalah bahwa pusaka Minangkabau tidak berubah dari dulu hingga sekarang, walaupun orang yang menjalankan pusaka adat tersebut sudah berganti dari satu generasi ke generasi berikutnya. Ungkapan adat di atas mengandung makna bahwa gelar Penghulu di Nagari Sungai Patai diwariskan secara turun temurun. Masyarakat Minangkabau memiliki adat yang unik dengan menganut sistem matrilineal. Adat istiadat Minangkabau mengatur tatanan masyarakatnya baik secara individu, kelompok maupun sosial. Tatanan kehidupan yang telah diatur tersebut menjadi pegangan hidup masyarakat Minangkabau. Adat merupakan kebudayaan secara utuh yang dapat berubah. Namun ada adat yang tidak dapat

Culture \& Society: Journal of Anthropological Research Vol. 3, No. 2, Th. 2021 
berubah, seperti kata pepatah:

"Kain dipakai usang, adaik dipakai baru"

Artinya:

Kain dipakai usang, adat dipakai baru

Pepatah tersebut bermakna bahwa pakaian ketika dipakai terus, lama kelamaan akan usang. Tetapi ketika adat dipakai terus menerus akan senantiasa awet/langgeng. Gelar Penghulu yang dipangku oleh seorang mamak akan diturunkan kepada seorang kemenakan yang dianggap pantas untuk menerima dan mengembangkannya. Aturan itu bertujuan agar garis keturunan Penghulu (pusako) dalam sebuah kaum tetap bertahan dan tidak berubah karena adanya pergeseran zaman.

"Penghulu" atau "Datuak" adalah sebutan atau gelar yang diberikan kepada pemimpin adat dalam masyarakat Minangkabau. Penghulu merupakan orang yang dituakan, dipilih dan dipercayakan untuk memimpin masyarakat dengan gelar "Datuak". Dalam kehidupan sosial dipakai sistem:

"karajo baiak bahimboan, karajo buruak samo-samo malarang."

Artinya:

Kerja baik diundang, kerja jelek sama-sama melarang

Maksudnya, pekerjaan baik dikabarkan, pekerjaan buruk sama-sama dilarang. Ungkapan adat diatas lebih merujuk pada pengaturan kehidupan sosial masyarakat Sungai Patai. Mereka hidup saling tolong menolong dan melakukan pekerjaan untuk kepentingan bersama dengan bergotong royong, sehingga apapun pekerjaan yang akan dikerjakan lazimnya diselesaikan bersama-sama. Keberadaan aturan tersebut diperkuat dengan adanya lembaga dan pengurus pemangku adat Nagari, Balai-balai Adat Nagari.

\section{Osongkapali}

Osongkapali merupakan upacara penyelenggaraan jenazah 'Penghulu suku' di Nagari Sungai Patai, Kecamatan Sungayang, Kabupaten Tanah Datar. Penghulu pada masyarakat Minangkabau adalah seorang pemimpin suku, yang lebih dikenal dengan niniak mamak dengan gelarnya Datuak. Upacara ini dilaksanakan ketika salah seorang Datuak meninggal dunia di Nagari Sungai Patai. Osongkapali adalah keranda untuk membawa jenazah penghulu suku yang meninggal dunia. Bedanya dengan keranda biasa adalah bagian atas atau penutupnya bermotif gonjong seperti atap rumah adat Minangkabau, Sementara ketika warga biasa meninggal hanya akan diusung menggunakan keranda seperti yang lazim dipakai di lingkungan kaum muslimin pada umumnya. Upacara penyelenggaraan jenazah Osongkapali terdapat simbol-simbol yang menggambarkan kehidupan Datuak sebelumnya, simbol tersebut berupa benda yang lazim dipakai oleh seorang penghulu. Setiap penghulu meninggal dunia upacara Osongkapali wajib untuk dilaksanakan.

\section{Osongkapali sebagai keranda jenazah}

Osongkapali merupakan sebuah keranda yang dimuat oleh dubalang nan ampek dari suku yang berbeda. Osongkapali berbahan dasar bambu dan pelepah daun enau. Para dubalang mengolah bahan dasar tersebut menjadi sebuah keranda jenazah yang disebut Osongkapali. Pada masa dahulu, masyarakat tidak menggunakan paku untuk membentuk sebuah Osongkapali. Mereka memakai tali dan sistem pasak dalam merangkai bambu tersebut. Cara ini sama dengan pembuatan rumah gadang di Minangkabau. Saat sekarang ini masyarakat sudah memakai paku 
sebagai alat untuk merakit bambu tersebut menjadi sebuah keranda dan sampai sekarangi bentuk fisik Osongkapali masih sama dengan bentuk yang lama. (A.R Dt Lelo Nan Putiah, 2017)

\section{Upacara Osongkapali bagi Penghulu Suku}

Bagi masyarakat Sungai Patai, kebesaran seorang penghulu tidak hanya digambarkan dari upacara pengangkatan (melewakan) gelar seorang penghulu, melainkan juga tergambar ketika Penghulu tersebut tutup usia. Masyarakat Sungai Patai melakukan penghormatan kepada penghulu dengan mengadakan upacara penyelenggaraan jenazah penghulu tersebut yang khas, yakni berdasarkan aturan adat yang telah diwarisi secara turun temurun (Osongkapali dalam terminologi setempat).

Hingga saat ini kegitan penyelenggaraan jenzah penghulu (Osongkapali) di Nagari Sungai Patai masih dilaksanakan secara konsisten. Upacara itu diselenggarakan dengan baik tanpa ada satu tahapan pun tertinggal. Masyarakat setempat masih mempertahankan tahapan-tahapan serta nilai-nilai yang terkandung di dalam upacara tersebut.

\section{Tahapan Persiapan Upacara Osongkapali}

\section{Baretong}

Baretong (berunding) di atas rumah adat kaum penghulu yang meninggal dunia, merupakan prosesi yang paling penting dari sekian banyak prosesi yang berkaitan dengan upacara Osongkapali.Dikatakan demikian, karena prosesi Baretong merupakan penentuan untuk melaksanakan prosesi-prosesi berikutnya. Setelah jenazah Datuak berada di dalam rumah orang tuanya. prosesi baretong baru bisa dilaksanakan. Sesuai dengan aturan adat Sungai Patai (adaik salingka nagari),semua penghulu yang ada wajib hadir di atas rumah tersebut tanpa terkecuali. Diikuti pula oleh para dubalang adat yang juga merupakan perangkat Kerapatan Adat Nagari(KAN). Jika ada penghulu yang berhalangan hadir atau sedang tidak berada di Nagari Sungai Patai, maka dia akan diwakili oleh Bundo Kanduang suku terkait. Bundo Kanduang tersebut diharuskan memakai Baju Kuruang dan memakai Tingkuluak Kain Panjang. Prosesi baretong dalam adat setempat berfungsi sebagai wadah perundingan para ninik mamak dan tokoh masyarakat untuk menetapkan letak Pandam pakuburan dari penghulu yang meninggal. Letak Pandam Pakuburan biasanya dalam adat Sungai Patai pada paretongan di Rumah Pangka atau sipokok. Datuak dari pihak bako akan meminta untuk dikuburkan di pandam pekuburan $b a k o$, apabila permintaan itu tidak dikabulkan,maka akan diganti dengan sehelai kain kafan dari bako yang harus dipakai. Setelah itu dari Datuak pihak anak juga akan meminta dikuburkan di pandam kaum sang anak. Jika tidak dikabulkan, maka dalam pepatah "indak makabuah tanah sabingkah, kapan salampih mintak dikabulkan"(tidak di kabulkan sebidang tanah, salampih kain kafan minta dikabulkan).

\section{Mengaji Adaik}

Prosesi mangkaji adaik adalah prosesi yang dilaksanakan setelah kesepakatan penetapan pandam pekuruburan tempat pemakaman jenazah penghulu tersebut. Mangkaji adaiak merupakan prosesi penentuan jumlah atau besaran hutang penghulu kepada nagari. Hutang tersebut dibebankan kepada kaum atau keluarga penghulu. Hutang yang dibayarkan itu dinamakan juga dengan utang adaik kepada monti yang merupakan salah satu petugas KAN (Kerapatan Adat Nagari).

Istilah pembayaran hutang seorang penghulu bukan berarti penghulu tersebut memiliki hutang ke nagari secara pribadi, tetapi hal itu bermaksud untuk menegakkan memilliki hutang ke nagari secara pribadi, tetapi hal itu bermaksud untuk menegakkan aturan adat yang telah disepakati, karena pada penganngkatan melewankan gelar penghulu diistilahkan dengan Kupang

Culture \& Society: Journal of Anthropological Research Vol. 3, No. 2, Th. 2021 
. Jumlah Kupang yang harus dibayar Penghulu diistilahkan dengan Kupang. Jumlah Kupang yang harus dibayar Penghulu mesti disepakati oleh para Datuak. Satu Kupang yang harus dibayarkan Penghulu mesti disepakati oleh para Datuak. Satu Kupang tidak diketahui jumlah pastinya bila dipadankan dengan mata uang rupiah maupun emas.

Menurut para Penghulu yang ada di nagari tersebut ada perbedaan besaran hutang yang dibebankan kepada Penghulu Pucuak dan penghulu Andiko. Misalnya Penghulu Pucuk yang meninggal dibebankan sebesar 32 Kupang dibayarkan dengan mata uang rupiah sebesar Rp.320.000 dan untuk Penghulu Andiko. Hanya dibebankan 24 Kupang dibayarkan dengan mata uang rupiah sebesar Rp. 240.000. Kupang merupakan sebuah nilai yang yang mengisyaratkan pada nilai mata uang yang dipakai pada zaman dahulu. Satuan besaran hutang Penghulu diistilahkan dengan kupang. Jumlah Kupang yang harus dibayarkan Penghulu juga mesti disepakati para Datuak. (A.R Dt Lelo Nan Putiah, 2017)

\section{Mancabiak Kain Kapan}

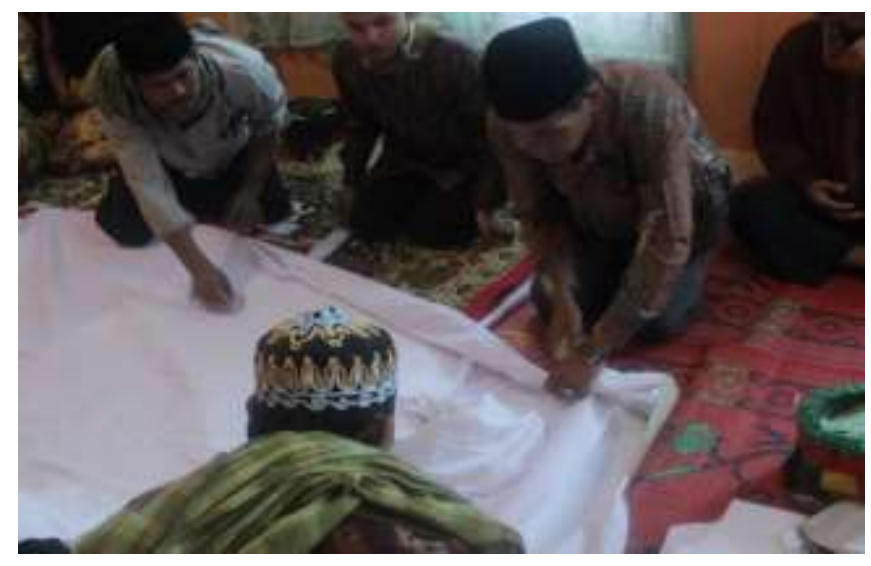

\section{Gambar 1. Kegiatan Merobek Kain Kapan}

Mancabiak kain kapan adalah kegiatan yang dilakukan oleh angku nan ampek (engku yang empat) berjumlah empat orang, mewakili suku yang ada di nagari Sungai Patai. Dalam prosesi mancabiak kain kapan tidak hanya angku nan ampek yang memiliki tanggung jawab penuh, akan tetapi tanggung jawab tetap dibebankan kepada semua pihak, terutama keluarga duka. Sementara angku nan ampek hanyalah sebagai simbol bahwa upacara kematian adalah tanggung jawab semua warga Nagari Sungai Patai. Setiap orang mempunyai tugas yang telah ditetapkan oleh niniak mamak berdasarkan hasil kesepakatan yang telah dicapai sebelumnya.

Dalam prosesi ini juga dibuat deta (kain ikat kepala) yang dalam istilah lokal disebut dengan kain deta putiah. Deta ini terbuat dari kain kafan. Deta ini digulung membantuk lingkaran yang nantinya diletakan pada bagian atas Osongkapali. Pembuatan deta ini dilakukan oleh dubalang nan ampek (dubalang yang empat). Setelah selesai deta itu diserahkan kepada seorang monti (manti).

\section{Pembuatan Keranda Osongkapali}

Culture \& Society: Journal of Anthropological Research Vol. 3, No. 2, Th. 2021 


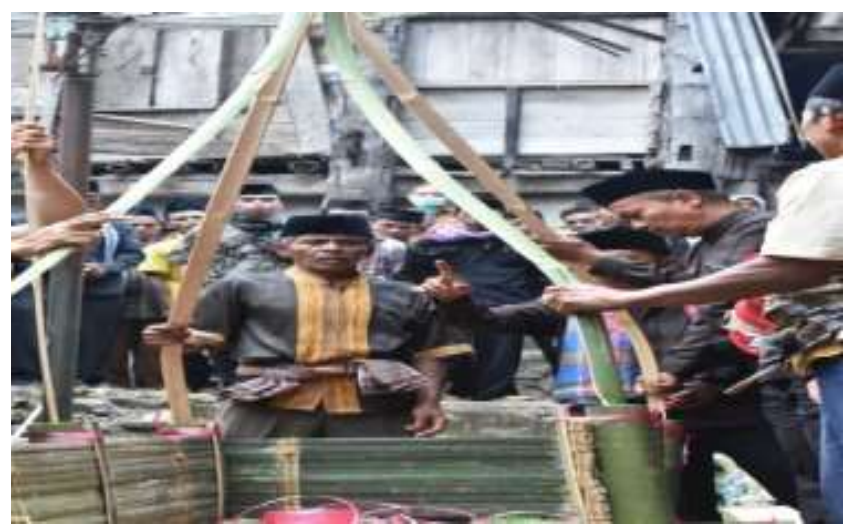

Gambar 2. Pembuatan Keranda Osongkapali

Osongkapali merupakan sebuah keranda yang dibuat oleh dubalang nan ampek yang mewakili suku berbeda. Osongkapali berbahan dasar bambu dan pelepah daun enau. Para dubalang mengolah bahan dasar tersebut menjadi sebuah keranda jenazah yang disebut Osongkapali. Pada masa dahulu masyarakat, tidak menggunakan paku untuk membentuk sebuah Osongkapali, tetapi hanya menggunakan tali dan sistem pasak untuk merangkai bambu tersebut. Cara ini sama dengan pembuatan rumah gadang di Minangkabau. Berbeda halnya dengan saat ini, warga masyarakat sudah memakai paku sebagai alat untuk merakit bambu tersebut menjadi sebuah keranda. Hanya saja secara fisik, bentuk Osongkapali masih sama dengan bentuk yang lama. Sementara Bundo Kanduang mengolah/mamasang kain adaiak (kain adat) untuk ditutupkan pada keranda adat. Pelibatan Bundo kanduang dalam hal ini adalah cerminan, bahwa sosok elit perempuan ini tidak boleh dilupakan atau diabaikan dalam masyarakat dan budaya Minangkabau. Bagaimanapun, peran bundo kanduang amatlah penting dan dihormati oleh masyarakat Minangkabau. Segala kebijaka yang akan diputuskan elit Minangkabau (niniak mamak, alim ulama, dan cadiak pandai) umumnya selalu didasarkan pada pertimbangan/ persetujuan dari pihak bundo kanduang.

Dalam Upacara kematian penghulu di Sungai Patai dapat dilihat bahwa peran bundo kanduang amatlah penting, seperti dalam pemasangan kain adat untuk menutupi Osongkapali telah dibuat oleh para dubalang tadi. Setelah Osongkapali dibuat, bundo kanduang akan menyalimuti keranda tersebut menggunakan kain adat yang merupakan kain yang telah turun temurun digunakan masyarakat dan sekaligus menjadi simbol adat istiadat dan kebesaran seorang penghulu di Minangkabau khususnya Nagari Sungai Patai. Dalam pemasangan kain adat hanya Bundo kanduang yang dibolehkan. Bundo Kanduang yang bertugas memasangkan berjumlah lima orang. Mereka berasal dari lima suku yang berbeda. Bundo Kanduang memiliki tanggung jawab penuh dalam pemasangan kain adat tersebut. Waktu memasang kain adat, bundo kanduang memakai pakaian adat yaitu memakai Baju kuruang dan Tingkuluak kain panjang. Bundo kanduang mengatur letak kain adat tersebut hingga menyelimuti Osongkapali secara keseluruhan.

\section{Tahapan Pelaksanaan Upacara Osongkapali}

\section{Mamasang Kain Adaik}

Culture \& Society: Journal of Anthropological Research Vol. 3, No. 2, Th. 2021 


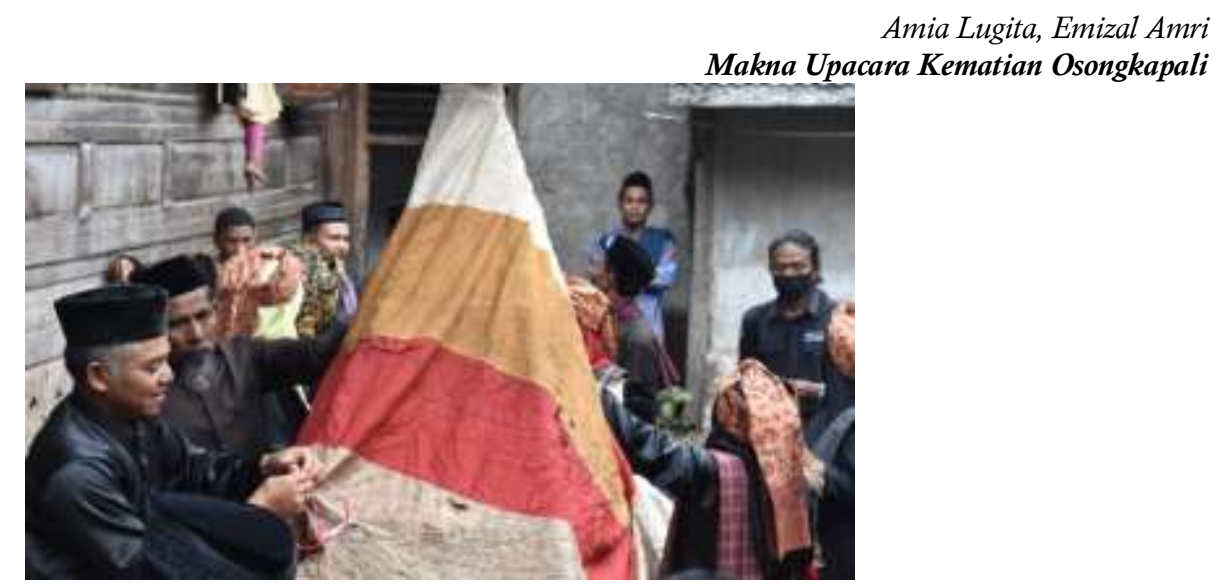

Gambar 3. Memasang Kain Adaik

Kain adat adalah kain yang ditutupkan pada keranda adat. Bundo kanduang adalah sosok yang tidak boleh terlupakan dalam Minangkabau, karena peran bundo kanduang amatlah penting dan dihormati oleh masyarakat Minangkabau. Segala kebijakan-kebijakan harus diketahui dan atas persetujuan bundo kanduang. Dalam Upacara kematian penghulu di Sungai Patai dapat dilihat bahwa peran bundo kanduang amatlah penting, seperti dalam pemasangan kain adat untuk menutupi Osongkapali telah dibuat oleh para dubalang tadi. Setelah Osongkapali dibuat, bundo kanduang akan menyalimuti keranda tersebut menggunakan kain adat yang merupakan kain yang telah turun temurun digunakan masyarakat dan sekaligus menjadi simbol adat istiadat dan kebesaran seorang penghulu di Minangkabau khususnya Nagari Sungai Patai.

Dalam pemasangan kain adat hanya Bundo kanduang yang dibolehkan. Bundo Kanduang yang bertugas memasangkan berjumlah lima orang. Mereka berasal dari lima suku yang berbeda. Bundo Kanduang memiliki tanggung jawab penuh dalam pemasangan kain adat tersebut. Waktu memasang kain adat, bundo kanduang memakai pakaian adat yaitu memakai Baju kuruang (baju kurung) dan Tingkuluak kain panjang (kain panjang untuk alas kepala). Bundo kanduang mengatur letak kain adat tersebut hingga menyelimuti Osongkapali secara keseluruhan.

\section{Maghocak}

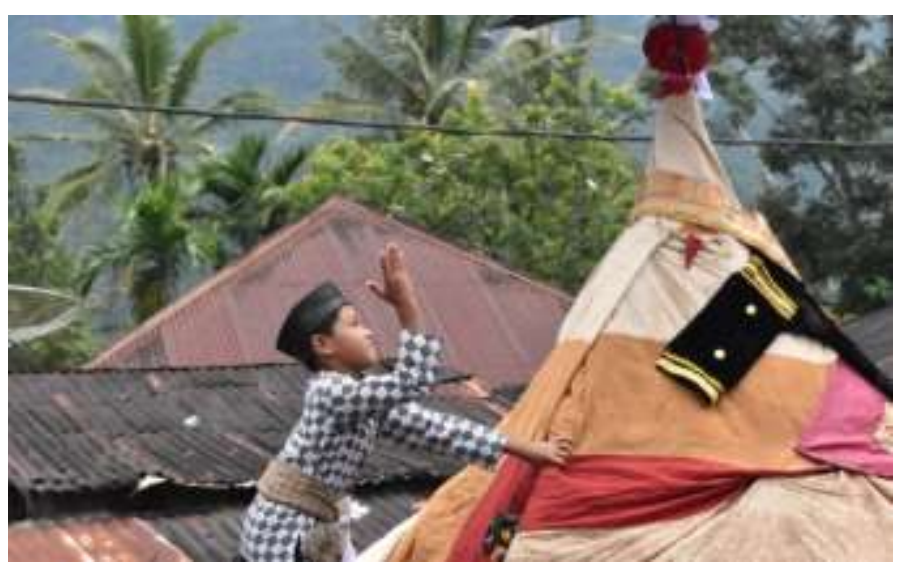

Gambar 4. Manghocak

Prosesi Marocak (menebarkan uang koin) merupakan prosesi yang paling unik dari sekian banyak rentetan dari prosesi Osongkapali. Marocak adalah kegiatan menebarkan uang koin kepada masyarakat di sepanjang jalan menuju pandam pakuburan penghulu dimaksud.

Culture \& Society: Journal of Anthropological Research Vol. 3, No. 2, Th. 2021 
Aktifitas Marocak dilakukan 'anak pisang' dari penghulu yang meninggal. Uang koin uang akan ditebar yaitu uang Rp.500,- dan uang Rp.1000,- dengan jumlahnya mencapai sekitar Rp.500.000,- uang yang ditebar disediakan oleh pihak sipangka atau pihak keluarga matrilineal yang ditinggalkan penghulu. Anak pisang yang marocak merupakan dari keluarga penghulu yaitu anak laki-laki berumur 8 tahun hingga laki-laki yang sudah dewasa. Untuk menjadi seorang penghulu di Minangkabau ada persyaratan-persyaratan yang harus dipenuhi. Salah satunya adalah memiliki harta pusaka. Kepemilikan harta itu juga tergambarkan dari prosesi Marocak, uang koin yang disebarkan sepanjang jalan akan dipungut masyarakat yang usianya mulai dari yang paling muda hingga paling tua.

Prosesi marocak lebih bermakna pada kekayaan yang dimiliki oleh seorang penghulu yaitu harta pusaka. Harta pusaka yang menjadi acuan dalam menebarkan uang koin didasarkan pada kekayaan kaum (keluarga matrilinealnya). Kemudian penebaran uang koin tersebut juga menyiratkan kemurah hati seorang penghulu dalam memimpin kaumnya.

Prosesi marocak berlangsung ketika jenazah penghulu sudah selesai diselenggarakan menurut ajaran agama Islam. Sebelum berangkat ke tempat jenazah akan dikuburkan, salah seorang yang disebut anak panca yaitu anak pisang dari penghulu tersebut menaiki Osongkapali. Setelah anak Panca naik ke atas Osongkapali masyarakat akan mengangkat keranda menuju Pandam Pakuburan (tempat perkuburan). Disepanjang jalan dari tempat jenazah disholatkan hingga pandam pakuburan. Anak Panca akan menebarkan uang koin dan masyarakat akan berebutan memunguti uang koin tersebut. Marocak dapat diartikan menaiki Osongkapali oleh anak panca adalah anak pisang yang bertalian darah langsung dengan penghulu yang meninggal. Tidak semua anak pisang dapat dikatakan anak panca dan menjadi perocak Osongkapali. Pemilihan anak panca ini berdasarkan anak pisang yang di rumah gadangnya juga ada penghulu. Anak panca ini harus memiliki darah penghulu atau anak keluarga penghulu.

\section{Tahapan Penutup Upacara Osongkapali}

\section{Pandam Pakuburan Sambakato Togak}

Disaat jenazah penghulu dikuburkan, salah seorang perwakilan dari pihak Sipangka melakukan Sambah Kato Togak (Sambuatan kata adat secara berdiri). Pihak Sipangka membacakan teks pasambahan Minangkabau yang disebut Pasambahan Alam. Pasambahan ditujukan kepada Datuak pucuak selaku perwakilan semua masyarakat yang telah hadir di Pandam Pakuburan tersebut. Pasambahan yang disampaikan perwakilan permintaan maaf dari keluarga Datuak (penghulu) yang meninggal.

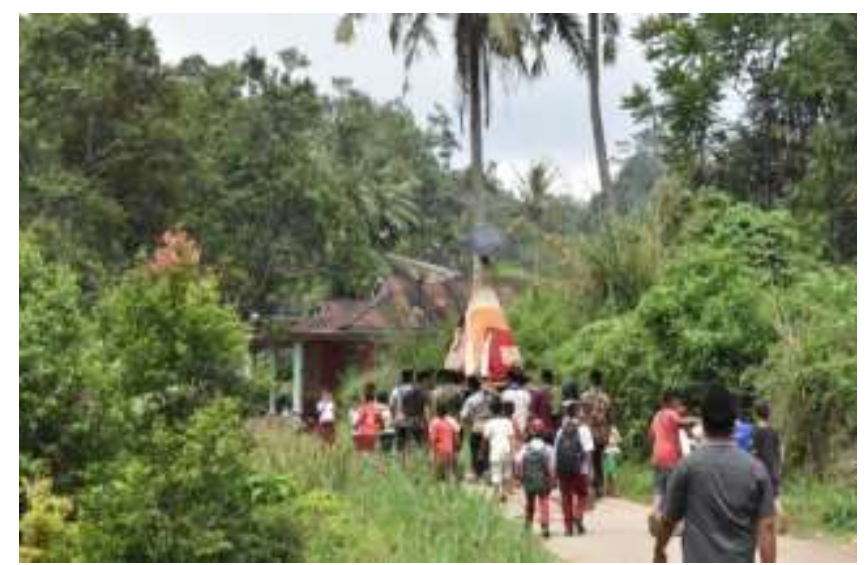

Gambar 5. Menuju Pandam Pakuburan

Culture \& Society: Journal of Anthropological Research Vol. 3, No. 2, Th. 2021 
Disaat itu pula Siriah Carano dilegakan kepada Penghulu-Penghulu yang hadir, makna Siriah Carano yaitu sebagai bentuk penghormatan dari tuan rumah kepada penghulu suku lain kaum. Setelah di bacakan Pasambahan Alam dilanjutkan dengan membacakan Do'a menurut ajaran agama Islam, agar jenazah ditempat ditempat yang terbaik disisinya.

\section{Manigo Ari (Melayat Kerumah Duka)}

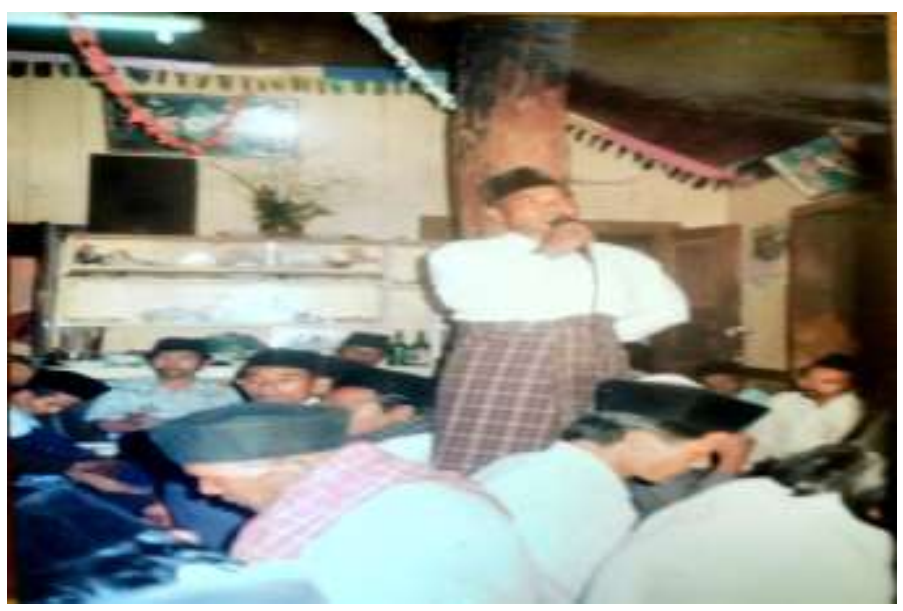

Gambar 6. Manigo Ari

Prosesi ini sudah umum dilaksanakan dalam setiap kematian di Sungai Patai. Manigo ari merupakan kegiatan menjenguk sekaligus mengajikan jenazah yang meninggal di rumah orang tua si almarhum atau di rumah keluarga matrilinealnya. Hari pertama setelah kematian biasanya yang hadir adalah keluarga terdekat, dan biasanya ini tidak ramai. Pada hari kedua, (dalam istilah setempat disebut dengan manigo ari kaum). Pelayat yang hadir pada malam kedua ini adalah kaum dari penghulu yang meninggal (Manigo Ari Sipokok). Pada hari ketiga ini adalah Manigo ari malam. Pada malam ketiga ini yang hadir warga nagari secara umum, tanpa memandang ikatan kekerabatan. Pada Manigo ari seluruh Penghulu dari suku lain wajib untuk menghadiri. Untuk menghormati Penghulu yang meninggal alur pasambahan dibawakan dengan posisi berdiri. Sikap dalam menyampaikan pasambahan dalam posisi berdiri disebut dengan Sambah kato togak. Pasambahan yang diucapkan disebut dengan pidato alam, teks pasambahan ( sambutan kata secara adat)-nya lebih panjang dari pidato alam yang disampaikan di Pandam Pakuburan. Acara manigo ari, ini biasanya 2 (dua) hari sebelumnya. Setelah selesai ayat-ayat al-quran para pelayat manigo hari pulang, tetapi kaum dari penghulu yang meninggal managa (menahan diri sejenak untuk tidak pulang). Tujuannya untuk silaturahmi antar kemenakan, menyelesaikan utang-piutang jenazah, serta menetapkan mambatuan kubua (memberikan batu kuburan). Keunikan dan perbedaaan manigo ari penghulu dan orang biasa, Terutama terletak pada pidato alam. Jika orang biasa yang meninggal tidak memakai pidato alam, namun setiap penghulu yang meninggal wajib menyampaikan pidato alam.

Pada umumnya di Minangkabau atau Sumatera Barat, pihak keluarga mengambil peran penting dalam upacara kematian. Penyelenggaraan jenazah sesuai dengan aturan-aturan agama Islam. Setelah aturan agama Islam dipedomani barulah diterapkan atau dijalankan aturan-aturan adat. Upacara kematian penghulu suku di Sumatera Barat pada umumnya tidak berbeda jauh dengan prosesi upacara kematian orang biasa. Upacara secara garis besar berlaku saat sebelum penguburan, dan sesudah penguburan.

\section{Makna Simbol Upacara Osongkapali}

Berdasarkan data di atas, maka dapat dikemukakan makna simbol osongkapali sebagai

Culture \& Society: Journal of Anthropological Research Vol. 3, No. 2, Th. 2021 
berikut;

Makna Bentuk Osongkapali yang menggambarkan seperti Rumah Adat Minangkabau.

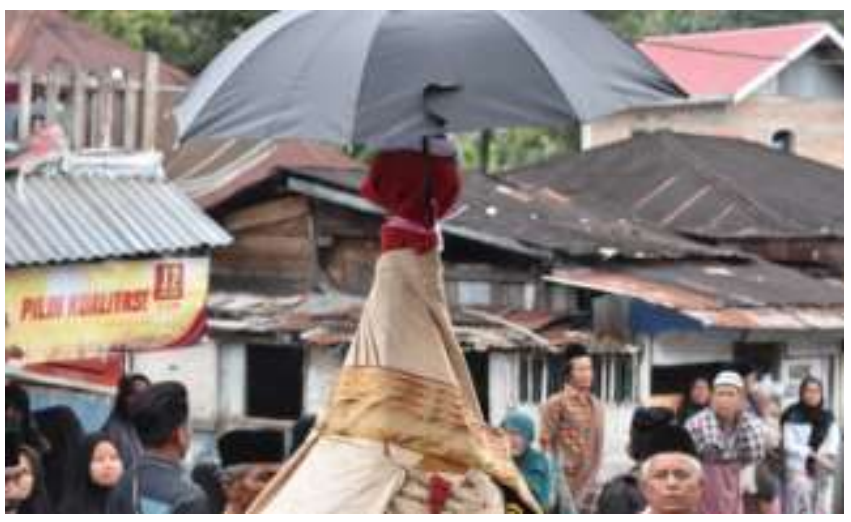

Gambar 7. Makna Bentuk Osongkapali

Kehidupan masyarakat tidak akan terlepas dari yang namanya adat istiadat. Terutama bagi Masyarakat Nagari Sungai Patai yang memiliki suatu keunikan dalam melaksanakan upacara kematian penghulu sukunya. Upacara kematian penghulu suku yang disebut Osongkapali memiliki simbol yang dapat memberikan sebuah makna. Osongkapali yang bentuknya menggambarkan seperti rumah adat minangkabau yaitu memiliki makna bagi masyarakat Nagari Sungai Patai sehingga dipertahankan hingga saat sekarang ini.

Diawali dengan pembuatan Osongkapali yang menggunakan bahan bambu dan pelepah enau, dua benda ini yang digunakan dalam pembuatan Osongkapali memiliki filosofi bambu yaitu untuk menguatkan dan enau itu artinya kuat. Osongkapali dibuat oleh Dubalang dari 4 pesukuan yang ada di Nagari Sungai Patai, lalu diiringi atau dibantu oleh masyarakat. Dahulu pembuatannya masih memakai sistem pasak yaitu tidak menggunakan paku karena teknologi pertukangan dalam Minangkabau tidak pernah memakai paku jadi sistem pasak berangkat dari proses pembuatan rumah adat minangkabau, tetapi saat sekarang ini masyarakat Nagari Sungai Patai sudah menggunakan paku dalam membuat keranda Osongkapali.

Makna simbol Osongkapali yang dibuat sepeti Rumah Adat Minangkabau yaitu masyarakat Nagari Sungai Patai memahami bahwa Osongkapali merupakan sebuah bentuk penghormatan terakhir kepada penghulu suku yang telah menjadi pemimpin dalam suatu kaum. Dari bentuk Osongkapali masyarakat paham agar upacara Osongkapali tetap dijalankan selama masyarakat masih ada, karena pada kehidupan sekarang kita wajib untuk mempertahankan kebudayaan yang sudah turun temurun agar selalu dijalankan dari generasi ke generasi.

Culture \& Society: Journal of Anthropological Research Vol. 3, No. 2, Th. 2021 


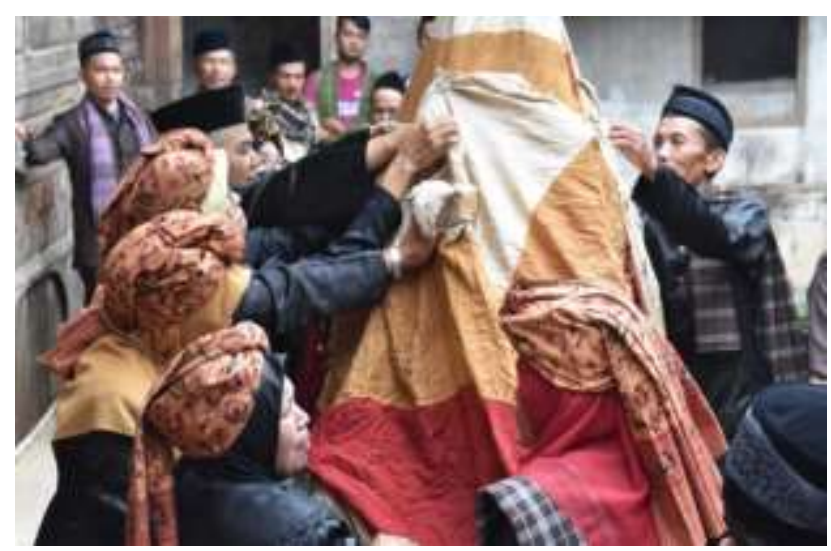

Gambar 8. Kain Raok

Kain adat merupakan kain yang digunakan untuk menutupi seluruh keranda Osongkapali yang disebut dengan Raok (kain penutup Osongkapali). Kain penutup sudah ada dari sejak zaman dahulunya. Kain penutup ini dibuat panjang sehingga bisa menutupi Osongkapali dan di pasangkan oleh bundo kanduang. Bundo Kanduang adalah sosok yang tidak boleh terlupakan dalam minangkabau, karena peran bundo kanduang amatlah penting dan di hormati oleh masyarakat minangkabau. Segala kebijakan-kebijakan harus diketahui dan atas persetujuan bundo kanduang.

Kain penutup dipasangkan oleh (5 lima) orang Bundo Kanduang dari keluarga Datuak Pucuak mulai dari atas sampai ke bawah dan sampai menutupi bagian mayat Datuak yang akan ditidurkan, andaikan ada dari ke 5 orang bundo kanduang salah satunya tidak hadir maka harus ditemui terlebih dahulu untuk menanyakan alasan mereka tidak hadir, jika alasan dari bundo kanduang bisa diterima maka bundo kanduang yang 4 (empat) orang sudah bisa memasangkan kain penutup Osongkapali. 5 (lima) orang bundo kanduang yang wajib memasangkan kain penutup merupakan orang terdepan dari penghulu yang lainnya, karena aturan ini sudah turun temurun dari nenek moyang zaman dahulu.

Makna kain penutup (Raok) atau Kain Adat yang dipakaikan oleh Bundo Kanduang dalam upacara Osongkapali yaitu Adat yang mengatur segala kehidupan masyarakat setiap orang yang ada di minangkabau. Kain adat memiliki 3 warna pada tiap warna tersebut memiliki makna yaitu putih, merah dan kuning. Makna kain yang berwarna putih adalah suci, makna kain merah adalah suatu kebesaran yang melambangkan keberanian, dan makna kain kuning adalah sebagai bentuk kebesaran bangsawan, upacara ini dilaksanakan agar generasi selanjutnya bisa memahami dan tepat dilaksanakan.

\section{Payung Hitam}

Culture \& Society: Journal of Anthropological Research Vol. 3, No. 2, Th. 2021 


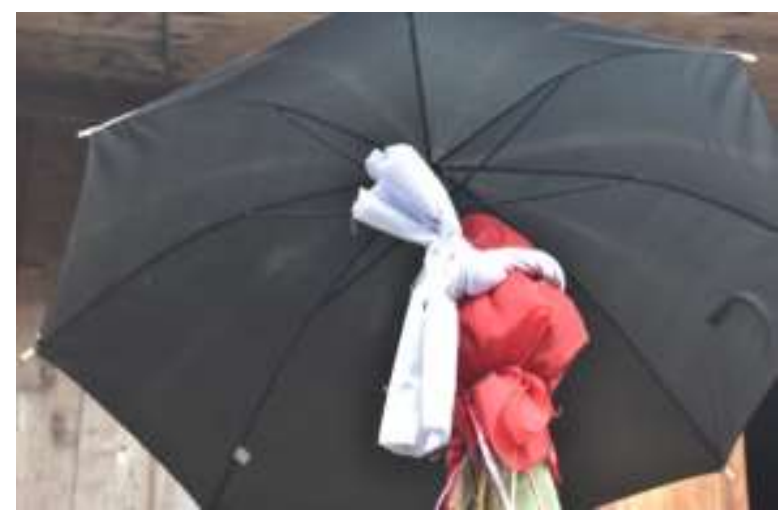

\section{Gambar 9. Payung Hitam}

Makna payung hitam yang dipasangkan pada puncak keranda Osongkapali yaitu melambangkan kebesaran seorang penghulu karena dengan payung hitamlah penghulu tersebut dipayungi ketika pengangkatan gelarnya sewaktu masih hidup dan ketika datuak meninggal juga dipayungi sampai beliau di makamkan. makna payung hitam ada pada upacara Osongkapali yaitu suatu tanda kebesaran dalam kaumnya dimana beliau sudah membimbing mulai dari anak, cucu, kemenakan dan kaum sukunya, dan makna payung hitam yaitu suatu pertanda bahwasanya orang terpandang yang meninggal yang patut dihormati walaupun beliau sudah meninggal tapi dengan cara tersebut dapat menghargai perjuangan beliau untuk tetap mempertahan kan adat istiadat dalam kaumnya.

\section{Kain semiri dan Kain Deta Putiah}

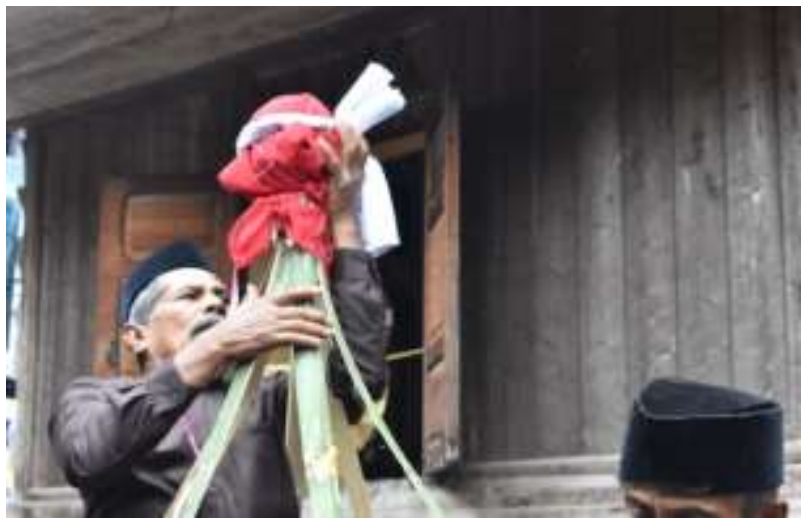

\section{Gambar 10. Kain Semiri dan Kain Deta Putiah}

Kain samiri dan kain deta putiah merupakan bentuk simbol yang melambangkan kebesaran seorang penghulu. Kain samiri dibuat menyerupai gumpalan yang merujuk pada sebuah kepala manusia kemudian dibungkus dengan kain berwarna merah. Kain deta putiah merupakan kain yang berwarna putih yang dililitkan ke gumpalan yang dilapisi kain semiri yang berwarna merah tersebut, pada acara batagak penghulu kain samiri yang menyerupai gumpalan kepala manusia dibuat dengan koran dan ketika penghulu meninggal gumpalan seperti kepala manusia tersebut dibuat dari daun pisang yang kering karena menggambarkan bahwa penghulu sudah meninggal, kedua kain ini melambangkan penghormatan terakhir yang diberikan kepada penghulu yang sudah meninggal dunia. 


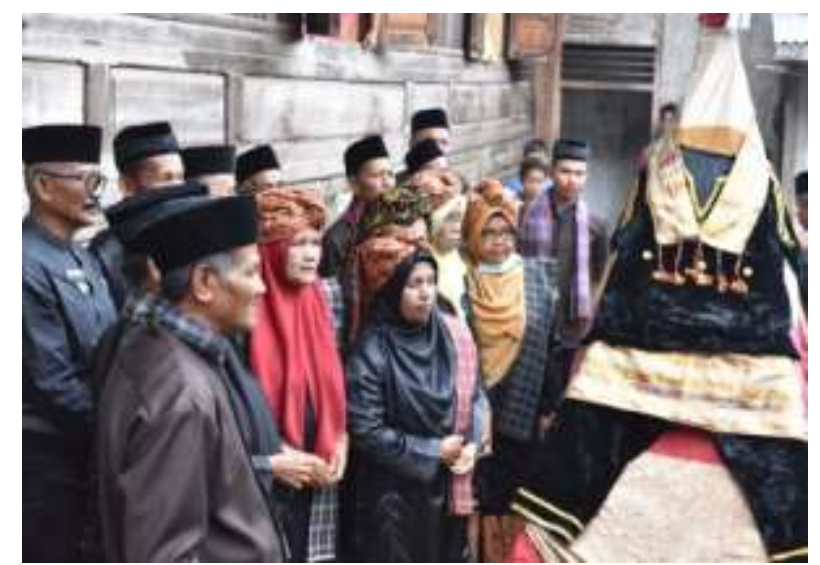

Gambar 11. Pakaian Penghulu

Di Kenagarian Sungai Patai kabupaten Tanah Datar terdiri dari bagian-bagian yang masing-masingnya mempunyai nama atau istilah. Nama atau istilah bagian-bagian pakaian penghulu diciptakan untuk mengisyaratkan pesan-pesan penting yang ingin disampaikan oleh nenek moyang terdahulu. Supaya pesan-pesan tersebut dapat diingat dan diamalkan oleh penghulu yang memakai pakaian Penghulu Minangkabau.

Pakaian penghulu tidak hanya dilihat sebagai sebuah benda yang berguna untuk menutupi seluruh tubuh dan keindahan saja, tetapi sama halnya dengan kebudayaan. Pakaian juga mempunyai nilai-nilai luhur dan pesan-pesan penting yang terkandung dari warisan budaya leluhur secara turun temurun. Sebagaimana yang kita ketahui dan kita lihat, pakaian Penghulu Minangkabau bukan hanya sebuah pakaian yang dibuat untuk seorang penghulu. Melainkan dibalik pembuatan pakaian tersebut terdapat hikmah dan falsafah yang mengandung ajaranajaran bagi si pemakainya (penghulu). Pada pakaian itu terkandung banyak sekali rahasia yang menyangkut sifat-sifat dan martabat serta larangan seorang penghulu begitupun tugasnya dan kepemimpinannya (Hakimy, 2001:104-105).

Setelah dipasangkan kain penutup Osongkapali, maka dipasangkan di bagian tengah Osongkapali Baju Penghulu, Sarawa Penghulu, Kain Saruang, tekek dan Karih, yang dikenakan semasa hidupnya. Hal ini dilakukan bertujuan untuk menghormati seorang penghulu dari pengangkatan gelar sampai ajal menjemputnya.

\section{Baju penghulu}

Seorang penghulu di Minangkabau umumnya memakai baju hitam lapang (longgar), artinya baju tersebut agak besar dengan lengan lapang (besar) pula. Bahannya terbuat dari beludru atau kain saten. Baju hitam lapang melambangkan bahwa baju penghulu bewarna hitam. Hitam diibaratkan bahwa seorang penghulu itu harus tabah dan tahan hati dalam melaksanakan tugas dan kewajibannya, sehingga apa yang dimaksud tercapai dengan sebaik-baiknya. Baju hitam lapang seorang penghulu melambangkan bahwa perkataan seorang penghulu tidak dapat dirubah lagi, hitam tetap hitam, karena yang dikatakan seorang penghulu merupakan hasil musyawarah bersama. Langan gadang, melambangkan seoarng penghulu berfikiran luas dam mempunyai sifat sabar serta melambangkan kepandaian dan kebijaksanaan seorang penghulu. Baju seorang penghulu tidak mempunyai saku, melambangkan seorang penghulu tidak akan melakukan kecurangan. Leher baju penghulu tidak berbuah/siba batanti melambangkan seorang penghulu tidak pandai menggunting dalam lipatan maksudnya seorang penghulu tidak mengambil keuntungan dari anak kemenakan. Baju seorang penghulu mempunyai leher yang lebar, melambangkan seorang penghulu bersifat lapang hati, pandai dalam segala hal dalam mengambil

Culture \& Society: Journal of Anthropological Research Vol. 3, No. 2, Th. 2021 
keputusan. Pada baju penghulu mempunyai taburan benang emas, yang melambangkan kekayaan alam Minangkabau.

Lengan baju penghulu itu lebar, ini berguna bagi penghulu sehingga dia bebas menggerakannya dan berarti penghulu wajib mengipas yang panas agar jadi dingin, sehingga tidak sampai hangus. Jika terjadi sangketa, perselisihan antara anak kemenakan dapat diselesaikannya. Sambungan badan dengan lengan diles dengan benang makau yang artinya mengulas tidak kelihatan membuhul tidak membuku. Lilitan benang makau melambangkan tanda kebesaran penghulu memegang peraturan, sehingga tangannya tidak dijangkaukan sekehendak hati. Leher bajunya berbelah ke bawah hampir ke dada dan tidak pakai buah. Ini melambangkan sebagai bayangan kesabaran. Seorang penghulu hendaklah berhati sabar, sebab sabar itu merupakan martabat bagi penghulu. Baju penghulu tidak mempunyai saku, melambangkan seorang penghulu tidak pernah berpura-pura. Baju penghulu tidak mempunyai saku, melambangkan seorang penghulu tidak boleh menggunting dalam lipatan, tidak boleh menjual harta pusaka tinggi, dan tidak boleh membawa harta anak kemenakan kerumah istri. Baju seorang penghulu juga tidak mempunyai buah, ini melambangkan bahwa seorang penghulu pandangannya luas dan alamnya lebar. Baju penghulu mempunyai lengan yang besar, ini melambangkan seorang penghulu harus selalu memberi nasehat kepada anak kemenakan, dan setiap hal-hal yangburuk tidak boleh disampaikan kepada anak kemenakan.

\section{Sarawa penghulu}

Celana penghulu berwarna hitam dan kakinya lebar. Terbuat dari kain saten atau beludru. Ini melambangkan agar seorang penghulu senantiasa melangkahkan kaki nya kejalan yang benar demi anak kemenakan dan orang-orang senagari. Celana penghulu longgar dimaksudkan agar penghulu tidak tersangkut dalam berjalan. Celana penghulu juga melambangkan agar seorang penghulu selalu berada di jalan yang lurus.

\section{Tekek}

Tekek adalah kain yang di ikat disamping biasa terbuat dari kain sutera warna merah dan ada juga yang berwarna hitam. Cara pemasangan tekek dengan cara melilitkan dari pinggang hingga 10 smpai 15 di atas lutut. Tekek melambangkan seorang penghulu mempunyai pengetahuan yang cukup dalam bidangnya. Tekek letaknya di atas lutut melambangkan semua tindakan panghulu harus ada ukurannya. Patut sedikit jangan banyak, patut tinggi jangan direndahkan (pantas sedikit jangan banyak, pantas tinggi jangan direndahkan) Pada tekek terdapat motif pucuak rabuang yang melambangkan semua anak kemenakan harus mendapat perlindungan dari penghulu. Tekek biasanya berwarna merah, bertaburkan benang makau serta beragi pucuk rebuang dan dalamnya di atas lutut. Warna merah melambangkan keberanian seorang penghulu melaksanakan kebenaran. Taburan benang makau melambangkan ilmu dan keberanian, artinya keberanian hendaknya dapat dipergunakan dalam negeri. Tekek juga melambangkan seorang penghulu berfikiran lapang dan berhati suci.

\section{Karih (keris)}

Keris adalah senjata kebesaran penghulu. Keris terbuat dari besi, sarungnya terbuat dari kayu. Keris dipakai pada upacara tertentu disertai kelengkapan pakaian penghulu. Keris pemasangannya diselipkan pada cawek (ikat pinggang). Letaknya condong ke kiri, agar tangan kanan mudah mempergunakan senjata itu. Apabila marah, keris harus diputar lebih dahulu ke kanan, setelah itu baru dipikir semasak- masaknya apa yang harus dilakukan. Hulunya terbuat dari kayu kamat, maksudnya segala sesuatu pekerjaan disesuaikan dengan adat lembaga. Keris itu bengkok. Ada yang bengkoknya dua setengah patahan ada juga yang lebih. Mata keris itu timbal balik, maksudnya kebesarannya diakui oleh anak kemenakan dan isi nagari. Matanya sangat tajam. Tajamnya itu tidak pernah melukai, artinya penghulu tidak mengikuti pendapat orang lain,

Culture \& Society: Journal of Anthropological Research Vol. 3, No. 2, Th. 2021 
karena ia percaya pada dirinya sendiri. Keris melambangkan ganti lidah oleh seorang penghulu. Keris melambangkan ilmu, paham dan keyakinan yang bulat unuk memelihara dan menjalankan kewajiban penghulu. Keris juga melambangkan seorang penghulu yang mempunyai kekuasaan untuk melindungi kaumnya. Makna pakaian adat yang di pasangkan pada kain penutup Osongkapali yaitu bentuk kebesaran penghulu dalam persukuannya, beliau sosok yang disegani oleh masyarakat, karena semasa hidupnya penghulu memiliki hati yang tabah dan sabar dalam menyikapi permasalahan yang ada pada kaummnya.

\section{Kesimpulan}

Berdasarkan hasil penelitian tentang upacara Osongkapali di Nagari Sungai Patai, kecamatan Sungayang, Kabupaten Tanah Datar, dapat ditarik kesimpulan: bahwa upacara Osongkapali memberikan makna dalam upacara tersebut, dengan memahami makna simbol tersebut masyarakat Sungai Patai dapat mempertahankan budaya yang sudah diwariskan secara turun temurun. Makna yang terdapat dari beberapa simbol pada upacara tersebut yaitu bentuk kebesaran penghulu dalam persukuannya, beliau sosok yang disegani oleh masyarakat, karena semasa hidupnya penghulu memiliki hati yang tabah dan sabar dalam menyikapi permasalaha yang ada pada kaummnya. Kain raok yang dipakaikan pada Osongkapali merupakan kebesaran yang melambangkan keberanian, sebagai bentuk kebesaran bangsawan. Seorang penghulu pandangannya luas dan alamnya lebar. melambangkan keberanian seorang penghulu melaksanakan kebenaran. Taburan benang makau melambangkan ilmu dan keberanian, artinya keberanian hendaknya dapat dipergunakan dalam nagari. Tekek juga melambangkan seorang penghulu berfikiran lapang dan berhati suci. Keris melambangkan ilmu, paham dan keyakinan yang bulat unuk memelihara dan menjalankan kewajiban penghulu. Keris juga melambangkan seorang penghulu yang mempunyai kekuasaan untuk melindungi kaumnya.

\section{Daftar Pustaka}

Dt. Lelo Nan Putiah. (2017). Adat Salingka Nagari Sungai Patai. Sungai Patai: KAN Sungai Patai. Alkaf, M. (2013). Berbagai Ragam Sajen pada Pementasan Tari Rakyat dalam Ritual Slametan. Gelar: Jurnal Seni Budaya, 11(2).

Darwis, R. (2016). Pohutu Molalungo pada masyarakat. Annual International Conference, 1-17.

Ernatip, E. (2018). Upacara 'Ngaben'di Desa Rama Agung-Bengkulu Utara. Jurnal Penelitian Sejarah dan Budaya, 4(2), 1115-1133.

Ramadhani, M., \& Fitriani, E. (2018). Relasi Simbol Pakaian "Anak Nagari” dalam Batarewai di Nagari Koto Gadang. Jurnal Perspektif, 1(4), 39-43.

Habsy, B. A. (2017). Seni memehami penelitian kuliatatif dalam bimbingan dan konseling: studi literatur. Jurnal Konseling Andi Matappa, 1(2), 90-100.

Hendro, E. P. (2020). Simbol: Arti, Fungsi, dan Implikasi Metodologisnya. Endogami: Jurnal Ilmiah Kajian Antropologi, 3(2), 158-165.

Rachmat, K. (2014). Pendekatan Critical Public Relations, Etnografi Kritis \& Kualitatif . Jakarta: Kencana.

Rukayat, A. (2018). Pendekatan Penelitian Kualitatif. Yogyakarta: CV. Budi Utama.

Setiawan, A. A. (2018). Metodologi Penelitian Kualitatif. Jawa Barat: CV Jejak.

Tsuroya, F. I. (2020). Kritik Etos, Pandangan Dunia, dan simbol-simbol Sakral. Jurnal Kajian, Penelitian \& Pengembangan Pendidikan Sejarah, 187-191. 